\title{
Bone Mass in Obese, Goldthioglucose-treated, Hyperglycaemic Mice
}

\author{
I. De Leeuw, P. Van Rooy, and M. D'Hollander \\ Laboratory of Endrocrinology and Metabolic Diseases, University of Antwerp (U.I.A.), Wilrijk, Belgium
}

\begin{abstract}
Summary. In contrast to insulin-dependent diabetics, bone mass in obese non-insulin dependent diabetics seems to be greater than in normal subjects. Hyperglycaemic, obese goldthioglucose mice were studied as a model for this last type of diabetes. A significantly greater cortical bone mass (cortical surface: $1.32 \mathrm{~mm}^{2}$ vs $1.15 \mathrm{~mm}^{2}$ for controls, $\mathrm{p}<0.01$ ) with enhanced bone apposition was found together with a significantly greater trabecular bone mass (trabecular surface $0.17 \mathrm{~mm}^{2}$ vs $0.13 \mathrm{~mm}^{2}, \mathrm{p}=0.05$ ) increasing bone solidity. The pathogenesis is unclear but hyperinsulinism and overnutrition may be contributory factors.
\end{abstract}

Key words: Bone mass, GTG-mice, obesity, noninsulin dependent diabetes

In insulin-dependent diabetics bone mass is often decreased compared with sex- and age-matched nondiabetic controls $[1,2,3,4]$.

Streptozotocin-diabetic rats, simulating the insulin-dependent state, have been found to have a decreased cortical bone mass [5]. In some groups of

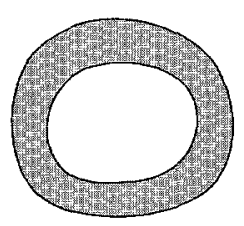

a

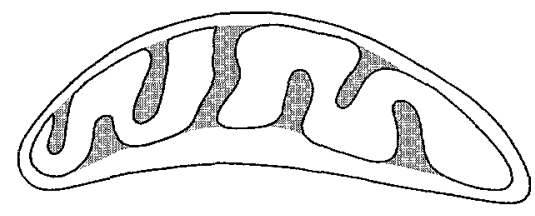

b
Fig. 1a and b. Diagram to demonstrate the method of calculation of surfaces occupied by bone surfaces in the femur (A) and ilium (B). a Cortical surface $=$ total surface - marrow surface. b Trabecular surface $\square=$ total surface - marrow surface - cortical surface non-insulin dependent diabetics, however, bone mass and bone density measured in the peripheral bones (hand, radius) were higher as compared to nondiabetic controls $[6,10,14]$. This finding was significantly related to the existence of a higher body weight in the diabetic patients. In order to evaluate the influence of obesity and hyperglycaemia on bone mass, goldthioglucose (GTG) mice served as an animal model for obese non-insulin dependent diabetes [7].

\section{Material and Methods}

One hundred and forty Swiss Albino female mice ( 3 weeks old) were injected IP with goldthioglucose (Sigma), $250 \mathrm{mg} / \mathrm{kg}$ body weight. Twenty-five control mice of the same age received the same volume of $0.154 \mathrm{~mol} / \mathrm{l}$ saline solution IP. Both groups were fed ad libitum with commercial chow. Body weight was recorded weekly. After 4 months 13 GTG mice and 1 control mouse had died. Of the remaining 127 GTG mice, $20(15 \%)$ were more than $50 \%$ overweight as compared to the mean weight of the controls.

After ether anaesthesia, blood was drawn by cardiac-puncture and fasting plasma glycaemia was measured by glucose-oxidase method (Boehringer). Immediately after death, the right femur and ilium-bones were carefully isolated by dissection and prepared for histologic examination. After plastic-embedding, fine slices [5] at the midshaft of the femur and the ilium were coloured with a modified Massonstaining following Duursma [8].

At the places examined, femur bone is of the compact, cortical type and the ilium is composed of a fine external layer of cortical bone with central trabeculae surrounded by bone marrow (Fig. 1).

Preparations were examined under the microscope and drawings were made under fixed magnification with the help of a Zeiss Zeichentubus.

Total surface and surfaces occupied by bone tissue were measured by planimetry (Fig. 1).

Left femur and ilium bones were ashed in a muffle furnace for $18 \mathrm{~h}$, in order to measure the percentage of bone ash (weight/ weight), representing the mineral content of the bone material.

Statistical evaluation was by standard parametric methods for mean \pm SEM the Student $t$ test, and correlation coefficients.

Results are given as mean \pm SEM. 
Table 1. Summary of histomorphometric data on femur-preparation from control and goldthioglucose (GTG) treated mice mean ( \pm SEM). Groups were compared using Student's t test

\begin{tabular}{lcll}
\hline & $\begin{array}{l}\text { Controls } \\
(\mathrm{n}=24)\end{array}$ & $\begin{array}{l}\text { Obese } \\
\text { GTG mice } \\
(\mathrm{n}=20)\end{array}$ & $\mathrm{p}$ \\
\hline Length femur $(\mathrm{mm})$ & 17.9 & 17.9 & $\mathrm{NS}$ \\
& $(0.2)$ & $(0.2)$ & \\
Total surface $\left(\mathrm{mm}^{2}\right)$ & 2.14 & 2.39 & $<0.05$ \\
& $(0.05)$ & $(0.08)$ & \\
Cortical surface $\left(\mathrm{mm}^{2}\right)$ & 1.15 & 1.32 & $<0.01$ \\
& $(0.04)$ & $(0.06)$ & $\mathrm{NS}$ \\
Marrow surface $\left(\mathrm{mm}^{2}\right)$ & 1.00 & 1.06 & \\
& $(0.04)$ & $(0.05)$ & \\
\hline
\end{tabular}

Table 2. Summary of histomorphometric data on ilium-preparation from control and goldthioglucose (GTG) treated rats. Significance was assessed using Student's t test mean ( \pm SEM)

\begin{tabular}{|c|c|c|c|}
\hline & $\begin{array}{l}\text { Controls } \\
(\mathrm{n}=24)\end{array}$ & $\begin{array}{l}\text { Obese } \\
\text { GTG mice } \\
(\mathrm{n}=20)\end{array}$ & $\mathrm{p}$ \\
\hline Total surface $\left(\mathrm{mm}^{2}\right)$ & $\begin{array}{c}1.85 \\
(0.08)\end{array}$ & $\begin{array}{c}1.85 \\
(0.07)\end{array}$ & NS \\
\hline Total bone surface $\left(\mathrm{mm}^{2}\right)$ & $\begin{array}{c}0.70 \\
(0.03)\end{array}$ & $\begin{array}{c}0.81 \\
(0.04)\end{array}$ & $<0.05$ \\
\hline Cortical surface $\left(\mathrm{mm}^{2}\right)$ & $\begin{array}{c}0.58 \\
(0.03)\end{array}$ & $\begin{array}{c}0.65 \\
(0.04)\end{array}$ & NS \\
\hline Trabecular surface $\left(\mathrm{mm}^{2}\right)$ & $\begin{array}{c}0.13 \\
(0.01)\end{array}$ & $\begin{array}{c}0.17 \\
(0.02)\end{array}$ & $=0.05$ \\
\hline Marrow surface $\left(\mathrm{mm}^{2}\right)$ & $\begin{array}{c}1.15 \\
(0.07)\end{array}$ & $\begin{array}{c}1.04 \\
(0.05)\end{array}$ & NS \\
\hline
\end{tabular}

\section{Results}

The mean body weight $(69 \pm 2 \mathrm{~g})$ and fasting blood glucose $(225 \pm 17 \mathrm{mg} / 100 \mathrm{ml})$ were significantly $(\mathrm{p}$ $<0.001$ and $\mathrm{p}<0.005$ ) higher in the 20 obese GTG mice as compared to the 24 controls (mean body weight $40 \pm 1$; mean fasting blood glucose $171 \pm$ $8 \mathrm{mg} / 100 \mathrm{ml}$ ). It should be noted that in controls and obese mice glucose was measured in the anaesthetised state which itself can cause hyperglycaemia.

The results of histomorphometric measurements are summarised in Table 1 for cortical bone and in Table 2 for trabecular bone.

Longitudinal growth of the long bones was identical in both groups. For cortical bone total and cortical surfaces were significantly greater in the obese GTG mice. Total surface $(\mathrm{r}=0.51)$ and cortical surface $(\mathrm{r}=0.46)$ were significantly $(\mathrm{p}<0.05)$ related to body weight but not to blood glucose values.
The total bone (cortical + trabecular) present in the ilium preparation and the trabecular bone surface were significantly higher in GTG obese mice. In GTG mice the trabecular surface was positively related $(\mathrm{r}=0.61, \mathrm{p}<0.01)$ to body weight but not to blood glucose values. The marrow spaces in both cortical and ilium preparations were not statistically different. Percentages of bone ash from the femur (76.2 $\pm 0.4 \%$ for controls vs $75.7 \pm 0.6 \%$ for GTG mice) and from the ilium ( $65.1 \pm 0.7 \%$ vs $67.0 \pm$ $0.6 \%$ ) were not significantly different.

\section{Discussion}

Histomorphometric measurements of cortical [5] and trabecular bone [9] in undecalcified plastic-embedded preparations are considered as reliable parameters of compact and spongious bone mass. With the use of these techniques, we have shown that in obese hyperglycaemic GTG mice, as in obese non-insulin dependent diabetics [10], a greater bone mass exists compared to normal matched controls.

Since many metabolic features (hyperinsulinism, hyperglycaemia, overweight, insulin-resistance) are common to obese diabetics and in GTG mice [7], it is tempting to consider the obese GTG mouse as a good model to study this type of diabetes. For this reason similar changes in bone mass are possibly due to similar aetiopathogenic mechanisms and experimental findings in the animal could give a new view on pathogenesis in man.

In the long bones, the longitudinal growth seems unaffected. In the compact bone tissue however the total bone surface is enlarged as well as the cortical bone surface, showing a stimulation of the periosteal bone growth, resulting in an enlargment of the total bone diameter. Since the marrow space is enlarged as compared to non-obese controls this seems to indicate that endosteal bone resorption is also stimulated.

Both phenomena are considered as physiological features of bone growth with age [11] and could be interpreted as an acceleration of the ageing process in the obese hyperglycaemic mice. The cortical bone mass however is maintained, protecting against the age-associated bone loss and fragility. Fluorochrome labelling [12] could prove differences in the distribution and thickness of new bone apposition between the groups.

In contrast to the long bones, the external dimensions of the spongious bones are identical in GTG mice and controls. The trabecular tissue however occupy more space in the marrow surface. This greater trabecular bone mass can give more solidity 
to the whole of the skeletal system. This observation looks important since clinicians [13] and radiologists [14] agree that post-menopausal osteopaenia is less frequent in obese, mostly diabetic, women when compared to thinner controls. The pathogenesis of this phenomenon is not clear.

Higher oestrogen levels in obese women [14] are not a sufficient explanation since the same observation was made in obese, diabetic men [10]. The anabolic effect of hyperinsulinism on bone growth could play a role. The possible stimulation of proteinsynthesis of the bone matrix [15-16] and enhanced mineral incorporation [17] in the presence of more insulin are in favour of this theory.

As in man [18], bone mineralization rate looks normal as shown by ash-weights and histological examination. This makes abnormal substrate or vitamin D metabolism unlikely.

The good correlation with body weight but not with blood glucose values suggests an influence of overnutrition. A similar hypothesis has been suggested in an experimental study in obese dogs [19], where animals with acquired obesity not only showed a greater bone mass but even the appearance of hyperostotic bone lesions as described in obese noninsulin dependent diabetics by Julkunen [20] and Forgacs [13]. Hyperostosis of the spine, the skull and several long bones in these patients is very similar and the frequency of age-associated bone fractures (hip, spine) seems to be smaller than in normalweight or thinner age- and sex matched controls. If overnutrition is at the origin of the greater bone mass the role of gastro-intestinal hormones and calcitonin, as suggested by Dalen [21], have also to be considered.

Acknowledgements. This work was possible with the financial help of a grant offered by the "Koningin Elisabeth-Stichting voor Geneeskundig, Wetenschappelijk Onderzoek".

\section{References}

1. Levin ME, Boisseau VC, Avioli LV (1976) Effects of diabetes mellitus on bone mass in juvenile and adult- onset diabetes. $\mathrm{N}$ Engl J Med 294: 241-245

2. Ringe JD, Kuhlencordt F, Kühnau IrJ (1976) Mineralgehalt des Skeletts bei Langzeitdiabetikern. Densitometrischer Beitrag zur "Osteopathia diabetica". Dtsch Med Wochenschr 101: $280-282$

3. Mc Nair P, Madsbad S, Christiansen C, Transbøl L, Faber OK, Binder C (1977) Bone mineral loss in diabetes mellitus. Acta Endocrinol [Suppl 209] (Kbh) 85: 45

4. Rosenbloom AL, Lezotte DC, Weber FT, Gudat J, Heller DR, Weber ML, Klein S, Kennedy BB (1977) Diminution of bone mass in childhood diabetes. Diabetes 26: 1052-1055
5. Brown DM, Jowsey $\mathbb{J}(1977)$ Osteoporosis in diabetic rats. Diabetes 26: 370

6. De Leeuw I, Abs R (1977) Bone mass and bone density in maturity type diabetics measured by the 125 I photon absorption technique. Diabetes 26: 1130-1135

7. Le Marchand Y, Jeanrenaud B, Freychet P (1977) Obésités expérimentales: étude de la résistance à l'insuline. In: Journées de Diabétologie, Hôtel-Dieu. Flammarion, Paris, p 157-166

8. Duursma SA, Visser WS, Zoeren MV, Korver MF (1969) A bone biopsy procedure. Calcif Tissue Res $4 ; 269-274$

9. Ellis HA, Peart KM (1972) Quantitative observations on mineralised and non mineralised bone in the iliac crest. J Clin Pathol 25: 277-286

10. De Leeuw IH (1979) The importance of body weight in the assessment of bone mass and bone density of maturity-type diabetics. In: Diabetes and obesity. Excerpta Medica, Amsterdam, p 259-262

11. Dequeker J, Remans J, Franssens R, Waes J (1971 b) Ageing patterns of trabecular and cortical bone and their relationship. Calcif Tissue Res 7: 23-30

12. Hammer WS, Soni HH, Fraleigh CM (1979) Quantitative study of bone activity in the diabetic rat mandible: triple fluorochrome study. Oral Surg 35: 718-719

13. Forgacs S (1974) Knochenveränderungen bei Diabetikern. Med Klin 69: 1971-78

14. Meema HE, Meema S (1967) The relationship of diabetes mellitus and body weight to osteoporosis in elderly females. Can Med Assoc J 96: 132-139 (1967)

15. Hahn JJ, Downing JJ, Phang JM (1969) Insulin effect on amino-acid transport in bone. Biochim Biophys Acta 184: 675-677

16. Cahalis EM, Dietrich JW, Maina DM, Raisz LG (1977) Hormonal control of bone collagen synthesis in vitro. Effects of insulin and glucagon. Endocrinology 100: 668-674

17. Mellerup ET (1974) Insulin effects on calcium, magnesium and phosphate metabolism in rats. Acta Endocrinol (Kbh) 75: 748-755

18. De Leeuw I, Vertommen J, Mulkens N, Abs R (1978) Mineral ash and osteoid tissue in the trabecular bone of diabetics. Medikon 7: 8-10

19. Hedhammer A, Fu-Ming Wu, Krook L, Schrijven H, De Lahunta A, Wahlen JP, Kallfelty FA, Nuney EA, Hintry HF, Sheffey BE, Ryan GD (1974) Experimental obesity by overnutrition in dogs. Cornell Vet [Suppl 5]

20. Julkunen H, Karava R, Viljanen V (1966) Hyperostosis of the Spine in Diabetes mellitus and acromegaly. Diabetologia 2: 123-126

21. Dalen N, Hallberg D, Lamke B (1975) Bone mass in obese subjects. Acta Med Scand 197: 353-355

Received: February 5, 1980, and in revised form: September 5, 1980

\section{H. De Leeuw}

Laboratory of Endocrinology and

Metabolic Diseases

University of Antwerp (U.I.A.)

1 Universiteitsplein

B-2610 Wilrijk

Belgium 